\title{
Trends in clinical use of targeted therapy for gastrointestinal cancers
}

\author{
Kojiro Eto, Masayuki Watanabe \\ Department of Gastroenterological Surgery, Cancer Institute Hospital, 3-8-31 Ariake, Koto-ku, Tokyo 135-8550, Japan.
}

Correspondence to: Dr. Masayuki Watanabe, Department of Gastroenterological Surgery, Cancer Institute Hospital, 3-8-31 Ariake, Koto-ku,

Tokyo 135-8550, Japan. E-mail: masayuki.watanabe@jfcr.or.jp

\section{A B S T R A C T}

Targeted drugs therapies that block the molecular pathways involved in the development and progression of gastro-intestinal (GI) cancers have recently gained considerable attention. In addition to agents targeting vascular endothelial growth factor (VEGF), epidermal growth factor receptor, the multi-kinase inhibitor, and regorafenib have also become available for the treatment of metastatic colorectal cancer patients. Currently, trastuzumab, an antibody targeting human epidermal growth factor receptor-2 (HER-2), in combination with cytotoxic drugs is considered as the standard treatment for patients with HER-2 positive gastric cancer (GC). The efficacy of ramucirumab, a human monoclonal antibody that inhibits VEGF from binding to its receptor in GC, has also been recently demonstrated. At present, a great number of novel targeted drugs are in pre-clinical or clinical studies. In this review, we summarize trends in the use of molecularly targeted drugs that have proven to be effective for treating GI cancers, with a focus on emerging strategies for personalized treatment.

Key words: Gastro-intestinal tumors, molecular pathways, molecular targeted drug

\section{Introduction}

Many targeted drugs have been studied to target the molecular pathways involved in the development of gastro-intestinal (GI) cancers. Targeted drugs therapies that block the molecular pathways involved in the development and progression of GI cancers have recently gained considerable attention. Several molecular pathways were reported. Vascular endothelial growth factor (VEGF) and epidermal growth factor receptor (EGFR), the multi-kinase inhibitor, regorafenib, have also become available for the treatment of metastatic colorectal cancer (mCRC) patients. Currently, trastuzumab, an antibody targeting human epidermal growth factor receptor-2 (HER-2), in combination with cytotoxic drugs is considered to be the standard treatment for patients with HER-2 positive gastric cancer (GC). The efficacy of ramucirumab, a human monoclonal antibody $(\mathrm{mAb})$ that inhibits VEGF from binding to its receptor in $\mathrm{GC}$, has also been recently demonstrated.

Although the above improvements have reduced GI cancers mortality in the past few decades, there is sufficient evidence suggesting that the majority of patients undergoing drug therapy will not benefit and will instead experience severe and even lethal adverse drug events. Therefore, new and better molecular targeted

\begin{tabular}{|l|l|}
\hline \multicolumn{2}{|c|}{ Access this article online } \\
\hline Quick Response Code: & Website: \\
\hline & www.jcmtjournal.com \\
\cline { 2 - 2 } & \\
\hline
\end{tabular}

therapies are needed. At present, a great number of novel targeted drugs are in pre-clinical or clinical studies.

The aim of this review is to provide a comprehensive overview of the state of art, focusing on the new emerging strategies in the personalized treatment of GI cancers and discussing about the possible implications for GI cancers therapy.

\section{The Main Pathways Targeted in Gastro-intestinal Tumors}

Many targeted drugs that block the molecular pathways involved in the development and progression of GI tumors have been studied. Some of these agents are most efficacious in combination with conventional chemotherapy regimens. The molecular targeted drugs that have been approved for the treatment of GI cancers are summarized in Table 1. We have reviewed representative pathways that serve as targets in GI cancers.

\section{Vascular endothelial growth factor pathway}

Angiogenesis is the process of new capillary formation from pre-existing blood vessels, and it

This is an open access article distributed under the terms of the Creative Commons Attribution-NonCommercial-ShareAlike 3.0 License, which allows others to remix, tweak, and build upon the work non-commercially, as long as the author is credited and the new creations are licensed under the identical terms.

For reprints contact: reprints@ @medknow.com

How to cite this article: Eto K, Watanabe M. Trends in clinical use of targeted therapy for gastrointestinal cancers. J Cancer Metastasis Treat 2015;1:163-71.

Received: 04-08-2015; Accepted: 02-09-2015. 
Table 1: Approved molecular targeted drugs in advanced gastro-intestinal tumors

\begin{tabular}{lllll}
\hline Primary cancer site & Targets & Drugs & OS (month) & Reference \\
\hline GC & HER-2 & Trastuzumab & 13.8 (first-line) & {$[51]$} \\
& VEGFR-2 & Ramucirumab & 9.6 (second-line) & {$[53]$} \\
CRC & VEGF & Bevacizumab & 20.3 (first-line) & {$[63]$} \\
& & Aflibercept & 13.5 (second-line) & {$[84]$} \\
& VEGFR, BRAF, KIT, RET, PDGFR & Regorafenib & 6.4 (third-line) & {$[81]$} \\
& EGFR & Cetuximab & 24.9 (first-line) & {$[75]$} \\
& & Panitumumab & 26.0 (first-line) & {$[78]$} \\
\hline
\end{tabular}

HER2: Human epidermal growth factor receptor 2; VEGFR-2: Vascular endothelial growth factor receptor-2; VEGF: Vascular endothelial growth factor; VEGFR: Vascular endothelial growth factor receptor; BRAF: V-Raf murine sarcoma viral oncogene homolog B1; KIT: Mast/ stem cell growth factor receptor; RET: Rearranged during transfection; PDGFR: Platelet-derived growth factor receptor; OS: Overall survival; EGFR: Epidermal growth factor receptor; CRC: Colorectal cancer; GC: Gastric cancer

plays an important role in the growth and spread of cancers. ${ }^{[1]}$ Neovascularization promotes tumor growth by supplying nutrients, oxygen and growth factors that promote tumor cell proliferation. ${ }^{[2,3]}$ VEGF was first isolated in 1983 as a factor that increases vascular permeability in tumors. ${ }^{[4]}$ The VEGF family of proteins comprises VEGF-A, -B, -C, -D and -E, and structurally resembles the platelet-derived growth factor (PDGF) and placenta growth factor (PLGF) families of proteins. These growth factors bind selectively, but with different affinity, to at least five distinct receptors. ${ }^{[5-7]}$ Many cytokines and growth factors, including PDGF, tumor necrosis factor, transforming growth factor (TGF)- $\alpha$, TGF- $\beta$, fibroblast growth factor (FGF)-4, keratinocyte growth factor/FGF-7, EGF, interleukin (IL)-1 $\alpha$, IL-1 $\beta$, IL-6 and insulin-like growth factor (IGF)-1, are involved in upregulating $V E G F$ gene expression. ${ }^{[8]}$ Overexpression of VEGF has been associated with increased microvessel density, tumor invasion, metastasis and thus with poor prognosis in many types of cancers. ${ }^{[9]}$

\section{Epidermal growth factor receptor pathway}

The EGFR family consists of four homologous receptors: The EGFR (ErbB1/EGFR/HER-1), ErbB2 (HER-2/neu), ErbB3 (HER-3) and ErbB4 (HER-4). ${ }^{[10]}$ EGFR is a 170 $\mathrm{kDa}$ cell surface tyrosine kinase (TK) transmembrane receptor that initiates signaling cascades leading to cell proliferation, motility, adhesion, invasion, cell survival and angiogenesis. ${ }^{[11]}$ Mutation in the TK domain of the $E G F R$ gene has been found in several types of cancers and has become a therapeutic target in non-small cell lung cancer $^{[12]}$ Overexpression and/or amplification of HER-2 has been observed in various cancers, ${ }^{[13-15]}$ including breast, esophageal and GCs at 7-34\% frequency, ${ }^{[16,17]}$ and several studies have shown that HER-2 is an important biomarker and a key driver of tumorigenesis. ${ }^{[18]}$ Therefore, blockade of the EGFR family should lead to the inhibition of cell growth, thereby constituting an effective anti-cancer therapy. ${ }^{[19]}$ However, cross-talk between the various ErbB receptors that may induce drug resistance has been demonstrated. ${ }^{[20]}$ Because the intra-cellular space is vastly complex, targeting more than one signaling pathway or blocking multiple targets within a single pathway may be necessary to effectively suppress cancer growth.

\section{Phosphatase and tensin homolog-phosphoinositide 3-kinase-AKT-mammalian target of rapamycin pathway}

Phosphoinositide 3-kinases (PI3Ks) are a family of lipid kinases that phosphorylate the 3'-hydroxyl group of phosphoinositides with the conversion of phosphatidylinositol-4, 5-biphosphate to phosphatidylinositol-3, -4, 5-trisphosphate (PIP3). PIP3 is a critical second messenger that activates protein kinase B (AKT) through phosphorylation. Once activated, phospho-AKT phosphorylates up to 100 other proteins, including the mammalian target of rapamycin (mTOR), which is part of the mTOR complex (mTORC) 1 and mTORC $2 .{ }^{[21,22]}$ The activation of mTOR increases cellular proliferation and survival and decreases apoptosis. In normal tissue, this pathway is negatively regulated by the tumor suppressor phosphatase on chromosome 10 (phosphatase and tensin homolog), which targets the lipid products of PI3K for dephosphorylation. ${ }^{[23]}$

\section{Ras-Raf-MEK-extra-cellular-signal-regulated kinase pathway (MAPK pathway)}

The Raf/mitogen-activated protein kinase (MAPK)/ extra-cellular-signal-regulated kinase (ERK) pathway is an important pro-survival signaling pathway, that is, primarily involved in cell growth and survival and regulation of cellular differentiation. This pathway transduces extra-cellular signals from membrane-bound TK receptors, such as EGFR, VEGF receptor (VEGFR), IGF receptor (IGFR), hepatocyte growth factor receptor (c-MET) and PDGF receptor (PDGFR), to the nucleus. Binding of growth factors results in receptor phosphorylation, which activates an adapter molecule complex. This sequence in turn activates the Raf/mitogen/extra-cellular protein kinase (MEK)/ERK pathway, which triggering a cascade of specific phosphorylation events. ${ }^{[2]}$ Within this pathway, the small GTPase Ras and the serine/threonine kinase Raf are the key signal regulators. ${ }^{[25]}$ Intermediate 
signaling is regulated by MEK1 and MEK2, which are responsible for phosphorylating and activating the final downstream signaling molecules ERK1 and 2. ${ }^{[23]}$ ERK1/2 regulates cellular activity by acting on more than 100 substrates, both in the cytoplasm and nucleus. Ras also regulates the $\mathrm{PI} 3 \mathrm{~K} / \mathrm{AKT} / \mathrm{mTOR}$, the phospholipase $\mathrm{C} /$ protein kinase $\mathrm{C}$, and the $\mathrm{Ral}$ guanine nucleotide dissociation stimulator pathways. ${ }^{[26,27]}$

\section{Wnt pathway}

Extensive descriptions of the roles of Wnt signaling in development and disease can be found in recent reviews. ${ }^{[28,29]}$ The canonical $\mathrm{Wnt} / \beta$-catenin signaling pathway involves the sequestration of $\beta$-catenin from a destruction complex, which consists of adenomatous polyposis coli glycogen synthase kinase $3-\alpha$, casein kinase 1 and axin. The activation of $\mathrm{Wnt} / \beta$-catenin signaling is important for both the initiation and progression of cancers in various tissues. ${ }^{[30]}$ Therefore, the disruption of $\mathrm{Wnt} / \beta$-catenin signaling represents an opportunity for rational cancer chemoprevention and therapy. ${ }^{[30]}$ In $\mathrm{CRC}, 90 \%$ of all tumors have a mutation in a key regulatory factor of the $\mathrm{Wnt} / \beta$-catenin signaling pathway that results in pathway activation, and up to $80 \%$ of tumors exhibit nuclear accumulation of $\beta$-catenin. ${ }^{[31-33]}$

\section{Nuclear factor- $\kappa B$ pathway}

In recent years, several studies have revealed the connection between inflammation and carcinogenesis. ${ }^{[34,35]}$ In chronic inflammation, cytokines and chemokines produced by inflammatory cells propagate a localized inflammatory response and enhance the survival of pre-malignant cells by activating the nuclear factor- $\kappa \mathrm{B} \quad(\mathrm{NF}-\kappa \mathrm{B})$ pathway. $\mathrm{NF}-\kappa \mathrm{B}$ is aberrantly activated in $50 \%$ of $\mathrm{CRC}$ patients and those with colitis-associated tumors, and mouse studies have established that NF- $\kappa \mathrm{B}$ plays a role in the development of colitis-associated cancer. ${ }^{[36,37]}$ As the NF- $\kappa B$ pathway plays a pivotal role in apoptosis, tumor promotion and maintenance, inhibitors of this signaling pathway would be useful in CRC therapy. Non-steroidal anti-inflammatory drugs (NSAIDs) exhibit anti-neoplastic activities in the colon. ${ }^{[38]}$ Stimulation of NF- $\kappa B$ expression is inhibited by various NSAIDs, indicating that NSAIDs may act as chemopreventive agents. Several studies, including randomized trials, have shown that regular use of NSAIDs is associated with decreased CRC incidence and mortality. ${ }^{[39,40]}$

\section{Clinical Application of Targeted Drugs}

\section{Esophageal cancer}

Esophageal cancer is the eighth most frequent cause of cancer death and is increasing worldwide. ${ }^{[41]}$ This malignancy comprises two major histologic types, esophageal squamous cell carcinoma (ESCC) and esophageal adenocarcinoma (EAC). ESCC and EAC differ substantially in their underlying etiology and tumorigenesis. A tri-modal treatment strategy consisting of radiotherapy, chemotherapy and surgery is standard for patients with local and/or advanced cancer of the esophagus. ${ }^{[42,43]}$ Unfortunately, as the 5-year survival rate remains $<15 \%$ the majority of patients at advanced stages of the disease fails to benefit from these treatments, ${ }^{[44]}$ and more effective therapies are eagerly awaited. Therefore, clinical trials of targeted drugs as monotherapy or in combination with conventional chemotherapy have been recently conducted for patients with esophageal cancer. However, a recent randomized Phase III trial demonstrated that the addition of cetuximab, a humanized mouse EGFR mAb, to capecitabine-cisplatin provided no additional benefit to chemotherapy alone in the first-line treatment of advanced esophagogastric AC. ${ }^{[45]}$ Similarly, the addition of panitumumab; another EGFR $\mathrm{mAb}$ to epirubicin; oxaliplatin and capecitabine did not increase overall survival (OS) of patients with advanced esophagogastric AC. ${ }^{[46]}$ However, nimotuzumab, a humanized EGFR mAb, in combination with standard chemotherapy (cisplatin plus 5-fluorouracil [5-FU]), has shown a good therapeutic response in a pilot study of patients with ESCC. ${ }^{[47]}$

VEGF is up-regulated in EAC, and overexpression of VEGF protein has been reported as a negative prognostic marker in ESCC. ${ }^{[9]}$ Therefore, VEGF may be a potential therapeutic target in esophageal cancers. Although Phase II trials demonstrated that the addition of bevacizumab to conventional chemotherapy improved response rates (RRs) in patients with esophagogastric $A C,{ }^{[48]}$ no Phase III trial has demonstrated a survival benefit of bevacizumab. ${ }^{[49]}$

The efficacy of molecular targeted drugs for esophageal cancer is still controversial. Further investigations to elucidate molecular mechanisms of esophageal cancer are needed to establish effective targeted treatment strategies.

\section{Gastric cancer}

GC is the fourth most commonly diagnosed cancer and the second leading cause of cancer mortality worldwide. ${ }^{[50]}$ Despite the recent progress in cancer treatment, the prognosis of patients with advanced GC remains poor. The understanding of molecular pathways involved in gastric carcinogenesis offers novel treatment options. When compared with chemotherapy alone, the HER-2-targeting antibody trastuzumabin combination with capecitabine/cisplatin was shown to improve the survival of advanced GC patients harboring HER-2 overexpression caused by gene amplification. ${ }^{[51]}$ Another agent with promising results in clinical trials is ramucirumab, an antibody targeting VEGFR-2. ${ }^{[52,53]}$ However, clinical trials have failed to demonstrate the benefit of agents targeting EGFR (cetuximab, panitumumab), ${ }^{[45,46]}$ VEGF-A (bevacizumab) ${ }^{[54]}$ or mTOR (everolimus). ${ }^{[55]}$ The results of Phase III trials to 
evaluate the efficacy of molecular targeted drugs in GC are summarized in Table 2.

\section{Trastuzumab}

Trastuzumab is a recombinant humanized $\mathrm{mAb}$ directed against the extra-cellular domain of HER-2. Amplification or overexpression of HER-2 has been observed in $7-34 \%$ of GC. ${ }^{[16,17,56]}$ A recent large-scale Phase III study (the ToGA trial) demonstrated that trastuzumab combined with cisplatin and capecitabine provided a significant survival advantage over chemotherapy alone in patients with HER-2-positive GC and confirming that HER-2 is a crucial therapeutic GC target. ${ }^{[51]}$ The median OS was 13.8 months in the trastuzumab plus chemotherapy group $(n=294)$ and 11.1 months in the chemotherapy alone group ( $n=290$; hazard ratio [HR]: $0.74 ; 95 \%$ confidence interval [CI]: $0.60-0.91 ; P=0.0046)$. In the subgroup with high HER-2 expression (defined as immunohistochemistry $2+$ and fluorescence in situ hybridization positive, immunohistochemistry $3+$ ), the median OS was 16.0 months in the trastuzumab plus chemotherapy group and 11.8 months in the chemotherapy alone group (HR: 0.65; 95\% CI: 0.51-0.83). Trastuzumab is the first molecularly targeted drug that has been proven efficacious against GC.

\section{Ramucirumab}

Ramucirumab is a human mAb that binds to VEGFR-2 and works as a receptor antagonist blocking the binding of VEGF to the receptor. A Phase I trial demonstrated its anti-tumor activity and anti-angiogenic effect over a wide range of doses, suggesting clinical efficacy. ${ }^{[57]}$ In the REGARD Phase III randomized trial, 355 patients were treated with best supportive care plus ramucirumab or placebo in a second-line setting. Both the median OS (5.2 vs. 3.8 months; HR: 0.776; 95\% CI: $0.603-0.998)$ and the median progression-free survival (PFS) (2.1 vs. 1.3 months; HR: 0.483; 95\% CI: $0.376-0.620)$ were significantly longer in the ramucirumab than the placebo group, and the safety profile of the drug was acceptable. ${ }^{[52]}$ In the RAINBOW Phase III trial, ramucirumab was used as a second-line treatment in addition to paclitaxel (665 patients). ${ }^{[53]}$ The addition of ramucirumab resulted in a significant survival benefit; the median OS increased from 7.4 to 9.6 months (HR: 0.807; 95\% CI: 0.678-0.962), and the median PFS increased from 2.9 to 4.4 months (HR: 0.635 ; $95 \% \mathrm{CI}$ : 0.536-0.752). ${ }^{[53]}$ Currently, a randomized Phase II trial investigating the efficacy of ramucirumab as a first-line treatment in GC is ongoing. ${ }^{[58]}$

\section{Colorectal cancer}

Estimated new cases of CRC exceed 1.2 million/year worldwide, with more than 600,000 deaths/year. ${ }^{[59]}$ Liver metastases are observed in $25 \%$ of CRC patients at the time of diagnosis and recurrence after surgery is often encountered. The 5-year survival rate of patients with distant metastases diseases is only $10-20 \%$, although that of patients without lymph node metastasis is more than $80 \%{ }^{[60]}$ The majority of CRC occurrences are sporadic, without the existence of family history or genetic pre-disposition, and the etiological factors for CRC tumorigenesis appear to be complex and heterogeneous. There has been significant progress in identifying distinct molecular pathways leading to CRC that include either increased function of oncogenes or loss of tumor suppressor genes. ${ }^{[61]}$ Currently, the recent introduction of molecular targeted drugs has improved the treatment of advanced CRC. Cetuximab and panitumumab (EGFR mAbs) and bevacizumab (VEGF, mAb) have ushered in a new era of targeted therapy for CRC. ${ }^{[62-65]}$ Table 3 summarizes molecular targeted drugs used to treat CRC.

\section{Bevacizumab}

Bevacizumab, developed in the early 1990s, is a recombinant, humanized immunoglobulin G1 (IgG1) $\mathrm{mAb}$ that effectively disrupts the interactions of all isoforms of VEGF-A with VEGFRs. ${ }^{[66]}$ Pre-clinical studies have demonstrated that bevacizumab exhibits a broad range of anti-tumor activity. ${ }^{[67]}$ The AVF2107 study, a trial to investigate the efficacy of bevacizumab combined with irinotecan, bolus 5-FU and leucovorin (LV) (IFL) for patients with previously untreated mCRC, ${ }^{[63]}$ demonstrated that the addition of bevacizumab to IFL improved the RR and prolonged OS. In another

Table 2: Results of completed Phase III trials with molecular targeted therapy in advanced GC

\begin{tabular}{|c|c|c|c|c|c|}
\hline Target & Trial & Regimen & Patients $(n)$ & OS (month) & $P$ \\
\hline HER2 & ToGA & Cisplatine, capecitabine or FU \pm trastuzumab & 584 & 13.8 versus 11.1 (first-line) & 0.0046 \\
\hline HER2 & LOGIC & Capecitabine, oxaliplatin \pm trastuzumab & 545 & 12.2 versus 10.5 (first-line) & 0.35 \\
\hline HER2 & TyTAN & Paclitaxel \pm lapatinib & 261 & 11.0 versus 8.9 (first-line) & 0.21 \\
\hline EGFR & EXPAND & Cisplatine, capecitabine \pm cetuximb & 679 & 9.4 versus 10.7 (first-line) & 0.95 \\
\hline EGFR & REAL3 & Oxaliplatin, capecitabine, epirubicin \pm panitumumab & 553 & 8.8 versus 11.3 (first-line) & 0.013 \\
\hline VEGFR-2 & REGARD & $\mathrm{BSC} \pm$ ramucirumab & 355 & 5.2 versus 3.8 (second-line) & 0.047 \\
\hline VEGFR-2 & RAINBOW & Paclitaxel \pm ramucirumab & 665 & 9.6 versus 7.4 (second-line) & 0.017 \\
\hline VEGFR-A & AVAGAST & Cisplatine, capecitabine or FU \pm bevacizumab & 774 & 12.1 versus 10.1 (first-line) & 0.10 \\
\hline mTOR & GRANITE-1 & $\mathrm{BSC} \pm$ everolimus & 633 & 5.4 versus 4.3 (second- or third-line) & 0.12 \\
\hline
\end{tabular}

HER2: Human epidermal growth factor receptor 2; EGFR: Epidermal growth factor receptor; VEGFR-2: Vascular endothelial growth factor receptor-2; VEGFR-A: Vascular endothelial growth factor receptor-A; mTOR: Mammalian target of rapamycin; OS: Overall survival; FU: Fluorouracil; BSC: Best supportive care; GC: Gastric cancer 
Table 3: Results of completed Phase III trials with molecular targeted therapy in advanced CRC

\begin{tabular}{|c|c|c|c|c|c|}
\hline Target & Trial & Regimen & Patients $(n)$ & OS (month) & $\boldsymbol{P}$ \\
\hline$\overline{\text { VEGF }}$ & AVF2107 & IFL \pm bevacizumab & 402 & $20.3 v s .15 .5$ (first-line) & $<0.001$ \\
\hline VEGF & N016966 & $\begin{array}{l}\text { FOLFOX } 4 \text { or XELOX } \pm \\
\text { bevacizumab }\end{array}$ & 701 & 21.3 vs. 19.9 (first-line) & 0.077 \\
\hline VEGF & TREE1/2 & $\begin{array}{l}\text { mFOLFOX } 6 \text { or XELOX } \pm \\
\text { bevacizumab }\end{array}$ & 260 & $\begin{array}{l}26.1 \text { vs. } 19.2 \text { (mFOLFOX6 first-line) } \\
24.6 \text { vs. } 17.2 \text { (XELOX first-line) }\end{array}$ & \\
\hline VEGF & VELOUR & FOLFIRI \pm aflibercept & 1,226 & 13.5 vs. 12.1 (second-line) & 0.0032 \\
\hline $\begin{array}{l}\text { VEGFR, BRAF, } \\
\text { KIT, RET, PDGFR }\end{array}$ & CORRECT & Regorafenib or placebo & 760 & $6.4 v s .5 .0$ & 0.0052 \\
\hline EGFR & CRYSTAL & $\begin{array}{l}\text { K-Ras WT } \\
\text { FOLFIRI } \pm \text { cetuximab }\end{array}$ & 348 & $23.5 v s .20 .0$ (first-line) & 0.0093 \\
\hline $\begin{array}{l}\text { EGFR } \\
\text { VEGF }\end{array}$ & FIRE-3 & $\begin{array}{l}\text { FOLFIRI } \pm \text { cetuximabor } \\
\text { FOLFIRI } \pm \text { bevacizumab }\end{array}$ & 592 & 28.7 vs. 25.0 (first-line) & 0.017 \\
\hline EGFR & PRIME & $\begin{array}{l}\text { K-Ras WT } \\
\text { FOLFOX } 4 \pm \text { panitumumab }\end{array}$ & 656 & 23.9 vs. 19.7 (first-line) & 0.17 \\
\hline EGFR & $\begin{array}{l}\text { Update } \\
\text { PRIME }\end{array}$ & $\begin{array}{l}\text { K-Ras WT/MT other Ras } \\
\text { FOLFOX } 4 \pm \text { panitumumab }\end{array}$ & 108 & 17.1 vs. 18.3 (first-line) & 0.31 \\
\hline
\end{tabular}

VEGF: Vascular endothelial growth factor; VEGFR: Vascular endothelial growth factor receptor; BRAF: V-Raf murine sarcoma viral oncogene homolog B1; KIT: Mast/stem cell growth factor receptor; RET: Rearranged during transfection; PDGFR: Platelet-derived growth factor receptor; EGFR: Epidermal growth factor receptor; OS: Overall survival; CRC: Colorectal cancer; IFL: 5-fluorouracil and leucovorin

Phase III clinical trial performed, ${ }^{[68]}$ patients with mCRC were randomly assigned to receive one of three different irinotecan-containing regimens: irinotecan plus infusional 5-FU and LV (FOLFIRI), modified IFL and irinotecan plus oral capecitabine and FOLFIRI plus bevacizumab. This latter group showed a higher RR and a longer PFS and median OS than patients receiving FOLFIRI without bevacizumab. Subsequent trials with oxaliplatin-based regimens produced less robust differences. ${ }^{[69-71]}$ In the Phase III trial NO16966, ${ }^{[71]}$ the effect of capecitabine and oxaliplatin was compared with that of infused 5-FU, LV and oxaliplatin (FOLFOX), with or without bevacizumab. As compared to chemotherapy alone, treatment with bevacizumab in addition to oxaliplatin-based therapy significantly improved OS and PFS. Another Phase III trial, the TREE study ${ }^{[70]}$ investigated the tolerability of oxaliplatin in combination with three different 5-FU regimens (continuous infusion, bolus and oral) with or without bevacizumab as a first-line therapy. The study showed that as compared to patients who received chemotherapy alone, patients treated with FOLFOX6 plus bevacizumab experienced improvements in overall response, OS and PFS.

However, there is a controversy regarding the use of adjuvant treatments in CRC. The NSABP PROTOCOL C-08 trial showed that the addition of bevacizumab for 1-year to a modified FOLFOX6 adjuvant regimen did not significantly prolong disease-free survival (DFS) in Stage II and III CRC. ${ }^{[72]}$ Similarly, the AVANT trial showed that bevacizumab did not prolong DFS when added to adjuvant chemotherapy in resected Stage III CRC, and OS data suggested a potential adverse effect with bevacizumab plus oxaliplatin-based adjuvant therapy. ${ }^{[73]}$

\section{Cetuximab}

Cetuximab is a recombinant, chimeric, human/murine IgG1 mAb that binds specifically to the extra-cellular domain of EGFR in normal and tumor cells, promoting receptor internalization and degradation without receptor phosphorylation and activation. ${ }^{[74}$ In the pivotal Phase II study, the BOND trial, patients with mCRC were randomized to various treatment groups. ${ }^{[62]}$ As compared to cetuximab alone, the combination of irinotecan and cetuximab significantly improved overall patient response, median OS and PFS. Retrospective analysis of KRAS status in the CRYSTAL trial has recently shown statistically significant differences in PFS and overall response between patients with wild-type $K R A S$ and those with mutant $K R A S$ treated with FOLFIRI plus cetuximab. ${ }^{[75]}$ In the Phase III study, the FIRE-3, by Heinemann et al. ${ }^{[76]}$ patients with mCRC were randomly assigned to FOLFIRI plus either cetuximab or bevacizumab. Patients in the cetuximab and bevizumab arms had similar times to disease progression, but those treated with cetuximab had a significantly improved OS. One of the problems of cetuximab treatment is an increased risk of severe adverse events. A meta-analysis to investigate severe adverse events in CRC patients, reported the most common severe adverse events to be neutropenia, diarrhea and rash. However, cetuximab was not associated with an increased risk of fatal adverse events. $^{[77]}$

\section{Panitumumab}

Panitumumab is a fully human, recombinant $\mathrm{IgG} 2 \mathrm{mAb}$ that binds specifically and with high affinity to the extra-cellular domain of EGFR in normal and tumor 
cells. Through competitive binding to EGFR ligands, panitumumab prevents EGFR dimerization, auto-phosphorylation and signaling, thereby inhibiting proliferation and promoting apoptosis. ${ }^{[78]}$ A Phase III study, the PRIME trial, evaluated the combination of FOLFOX4 with panitumumab or FOLFOX4 alone as first-line treatment. ${ }^{[79]}$ As compared to chemotherapy alone, the combination therapy significantly improved PFS and increased RR in patients with wild-type $K R A S$. A non-significant increase in OS was also observed. In order to assess the efficacy and safety of FOLFOX4 with panitumumab as compared to FOLFOX4 alone according to KRAS (exon 2-4) and NRAS (exon 2-4) mutation status, data from the PRIME trial were analyzed. ${ }^{[80]}$ Patients without any Ras mutation who were treated with panitumumab had a significantly longer OS and PFS than those treated with chemotherapy alone.

\section{Regorafenib}

Regorafenib is an inhibitor of PDGFRs, c-KIT, FGF receptor and VEGF1-3. ${ }^{[81]}$ In the pivotal Phase III study, the CORRECT trial, patients with mCRC who had progressed after undergoing treatment with approved drugs were randomly assigned to regorafenib or placebo. ${ }^{[82]}$ As compared to placebo, treatment with regorafenib significantly prolonged OS and PFS, suggesting a potential new line of therapy with survival benefits for patients who have progressed after all standard therapies.

\section{Aflibercept}

Aflibercept is a recently developed, multiple angiogenic factors trap that inhibits not only VEGF-A, VEGF-B and PLGF, from activating their native receptor (VEGFR-1). ${ }^{[83,84]}$ Aflibercept has a higher VEGF-A binding affinity than bevacizumab. The velour trial evaluated FOLFIRI plus aflibe receptor FOLFIRI alone after progression on an oxaliplain-based chemotherapy. ${ }^{[85]}$ As compared to chemotherapy alone, the addition of bevacizumab significantly improved OS.

\section{Conclusion}

The clinical application of molecular targeted drugs has improved the survival of patients with GI cancers. We believe that both the identification of novel targets and the development of new drugs targeting several important pathways such as c-MET, rearranged during transfection, MEK and IGF/IGFR will contribute to further improvements in treatment results and the realization of personalized treatments for GI cancer.

\section{Financial support and sponsorship}

Nil.

\section{Conflicts of interest}

There are no conflicts of interest.

\section{References}

1. Sarmiento R, Longo R, Gasparini G. Antiangiogenic therapy of colorectal cancer: state of the art, challenges and new approaches. Int J Biol Markers 2012;27:e286-94.

2. Gavalas NG, Liontos M, Trachana SP, Bagratuni T, Arapinis C, Liacos C, Dimopoulos MA, Bamias A. Angiogenesis-related pathways in the pathogenesis of ovarian cancer. Int $\mathrm{J} \mathrm{Mol} \mathrm{Sci}$ 2013;14:15885-909.

3. Pang RW, Poon RT. Clinical implications of angiogenesis in cancers. Vasc Health Risk Manag 2006;2:97-108.

4. Senger DR, Galli SJ, Dvorak AM, Perruzzi CA, Harvey VS, Dvorak HF. Tumor cells secrete a vascular permeability factor that promotes accumulation of ascites fluid. Science 1983;219:983-5.

5. Shalaby F, Rossant J, Yamaguchi TP, Gertsenstein M, $\mathrm{Wu}$ XF, Breitman ML, Schuh AC. Failure of blood-island formation and vasculogenesis in Flk-1-deficient mice. Nature 1995;376:62-6.

6. Kawasaki T, Kitsukawa T, Bekku Y, Matsuda Y, Sanbo M, Yagi T, Fujisawa H. A requirement for neuropilin-1 in embryonic vessel formation. Development 1999;126:4895-902.

7. Fong GH, Rossant J, Gertsenstein M, Breitman ML. Role of the Flt-1 receptor tyrosine kinase in regulating the assembly of vascular endothelium. Nature 1995;376:66-70.

8. Robinson CJ, Stringer SE. The splice variants of vascular endothelial growth factor (VEGF) and their receptors. J Cell Sci 2001;114:853-65.

9. Kleespies A, Guba M, Jauch KW, Bruns CJ. Vascular endothelial growth factor in esophageal cancer. J Surg Oncol 2004;87:95-104.

10. Gerber HP, McMurtrey A, Kowalski J, Yan M, Keyt BA, Dixit V, Ferrara N. Vascular endothelial growth factor regulates endothelial cell survival through the phosphatidylinositol 3'-kinase/Akt signal transduction pathway. Requirement for Flk-1/KDR activation. J Biol Chem 1998;273:30336-43.

11. Robinson KW, Sandler AB. EGFR tyrosine kinase inhibitors: difference in efficacy and resistance. Curr Oncol Rep 2013;15:396-404.

12. Mitsudomi T. Molecular epidemiology of lung cancer and geographic variations with special reference to EGFR mutations. Transl Lung Cancer Res 2014;3:205-11.

13. Li Q, Wang D, Li J, Chen P. Clinicopathological and prognostic significance of HER-2/neu and VEGF expression in colon carcinomas. BMC Cancer 2011;11:277.

14. Witton CJ, Reeves JR, Going JJ, Cooke TG, Bartlett JM. Expression of the HER1-4 family of receptor tyrosine kinases in breast cancer. J Pathol 2003;200:290-7.

15. Reichelt U, Duesedau P, Tsourlakis M, Quaas A, Link BC, Schurr PG, Kaifi JT, Gros SJ, Yekebas EF, Marx A, Simon R, Izbicki JR, Sauter G. Frequent homogeneous HER-2 amplification in primary and metastatic adenocarcinoma of the esophagus. Mod Pathol 2007;20:120-9.

16. Gravalos C, Jimeno A. HER2 in gastric cancer: a new prognostic factor and a novel therapeutic target. Ann Oncol 2008;19:1523-9.

17. Tanner M, Hollmen M, Junttila TT, Kapanen AI, Tommola S, Soini Y, Helin H, Salo J, Joensuu H, Sihvo E, Elenius K, Isola J. Amplification of HER-2 in gastric carcinoma: association with topoisomerase II alpha gene amplification, intestinal type, poor prognosis and sensitivity to trastuzumab. Ann Oncol 2005;16:273-8.

18. Begnami MD, Fukuda E, Fregnani JH, Nonogaki S, Montagnini AL, da Costa WL Jr, Soares FA. Prognostic implications of altered human epidermal growth factor 
receptors (HERs) in gastric carcinomas: HER2 and HER3 are predictors of poor outcome. J Clin Oncol 2011;29:3030-6.

19. Fakih M. Targeting mechanisms of resistance to anti-EGF receptor therapy in KRAS wild-type colorectal cancer: the path to more personalized medicine. Future Oncol 2013;9:551-60.

20. Bronte G, Terrasi M, Rizzo S, Sivestris N, Ficorella C, Cajozzo M, Di Gaudio F, Gulotta G, Siragusa S, Gebbia N, Russo A. EGFR genomic alterations in cancer: prognostic and predictive values. Front Biosci (Elite Ed) 2011;3:879-87.

21. Engelman JA, Luo J, Cantley LC. The evolution of phosphatidylinositol 3-kinases as regulators of growth and metabolism. Nat Rev Genet 2006;7:606-19.

22. Silvestris N, Tommasi S, Petriella D, Santini D, Fistola E, Russo A, Numico G, Tonini G, Maiello E, Colucci G. The dark side of the moon: the PI3K/PTEN/AKT pathway in colorectal carcinoma. Oncology 2009;77 Suppl 1:69-74.

23. Roberts LR, Gores GJ. Hepatocellular carcinoma: molecular pathways and new therapeutic targets. Semin Liver Dis 2005;25:212-25.

24. Avila MA, Berasain C, Sangro B, Prieto J. New therapies for hepatocellular carcinoma. Oncogene 2006;25:3866-84.

25. Kolch W. Meaningful relationships: the regulation of the Ras/Raf/MEK/ERK pathway by protein interactions. Biochem J 2000;351(Pt 2):289-305.

26. Harden TK, Sondek J. Regulation of phospholipase C isozymes by ras superfamily GTPases. Annu Rev Pharmacol Toxicol 2006;46:355-79.

27. To MD, Perez-Losada J, Mao JH, Balmain A. Crosstalk between Pten and Ras signaling pathways in tumor development. Cell Cycle 2005;4:1185-8.

28. Gill S, Loprinzi CL, Sargent DJ, Thome SD, Alberts SR, Haller DG, Benedetti J, Francini G, Shepherd LE, Francois Seitz J, Labianca R, Chen W, Cha SS, Heldebrant MP, Goldberg RM. Pooled analysis of fluorouracil-based adjuvant therapy for stage II and III colon cancer: who benefits and by how much? J Clin Oncol 2004;22:1797-806.

29. Fearon ER. Molecular genetics of colorectal cancer. Annu Rev Pathol 2011;6:479-507.

30. Gupta A, Verma A, Mishra AK, Wadhwa G, Sharma SK, Jain CK. The Wnt pathway: emerging anticancer strategies. Recent Pat Endocr Metab Immune Drug Discov 2013;7:138-47.

31. Martensson A, Oberg A, Jung A, Cederquist K, Stenling R, Palmqvist R. Beta-catenin expression in relation to genetic instability and prognosis in colorectal cancer. Oncol Rep 2007; 17:447-52

32. Wanitsuwan W, Kanngurn S, Boonpipattanapong $T$, Sangthong R, Sangkhathat S. Overall expression of beta-catenin outperforms its nuclear accumulation in predicting outcomes of colorectal cancers. World $J$ Gastroenterol 2008; $14: 6052-9$

33. Elzagheid A, Buhmeida A, Korkeila E, Collan Y, Syrjanen K, Pyrhonen S. Nuclear beta-catenin expression as a prognostic factor in advanced colorectal carcinoma. World J Gastroenterol 2008; $14: 3866-71$

34. Okayama H, Schetter AJ, Harris CC. MicroRNAs and inflammation in the pathogenesis and progression of colon cancer. Dig Dis 2012;30 Suppl 2:9-15.

35. Hagemann T, Balkwill F, Lawrence T. Inflammation and cancer: a double-edged sword. Cancer Cell 2007;12:300-1.

36. Greten FR, Eckmann L, Greten TF, Park JM, Li ZW, Egan LJ, Kagnoff MF, Karin M. IKKbeta links inflammation and tumorigenesis in a mouse model of colitis-associated cancer. Cell 2004;118:285-96.

37. Kojima M, Morisaki T, Sasaki N, Nakano K, Mibu R,
Tanaka M, Katano M. Increased nuclear factor-kB activation in human colorectal carcinoma and its correlation with tumor progression. Anticancer Res 2004;24:675-81.

38. Shiff SJ, Koutsos MI, Qiao L, Rigas B. Nonsteroidal antiinflammatory drugs inhibit the proliferation of colon adenocarcinoma cells: effects on cell cycle and apoptosis. Exp Cell Res 1996;222:179-88.

39. Algra AM, Rothwell PM. Effects of regular aspirin on long-term cancer incidence and metastasis: a systematic comparison of evidence from observational studies versus randomised trials. Lancet Oncol 2012;13:518-27.

40. Flossmann E, Rothwell PM. Effect of aspirin on long-term risk of colorectal cancer: consistent evidence from randomised and observational studies. Lancet 2007;369:1603-13.

41. Zhang Y. Epidemiology of esophageal cancer. World $J$ Gastroenterol 2013;19:5598-606.

42. Homs MY, v d Gaast A, Siersema PD, Steyerberg EW, Kuipers EJ. Chemotherapy for metastatic carcinoma of the esophagus and gastro-esophageal junction. Cochrane Database Syst Rev 2006; CD004063.

43. Mauer AM, Kraut EH, Krauss SA, Ansari RH, Kasza K, Szeto L, Vokes EE. Phase II trial of oxaliplatin, leucovorin and fluorouracil in patients with advanced carcinoma of the esophagus. Ann Oncol 2005;16:1320-5.

44. Enzinger PC, Mayer RJ. Esophageal cancer. $N$ Engl J Med 2003;349:2241-52.

45. Lordick F, Kang YK, Chung HC, Salman P, Oh SC, Bodoky G, Kurteva G, Volovat C, Moiseyenko VM, Gorbunova V, Park JO, Sawaki A, Celik I, Gotte H, Melezinkova H, Moehler M. Capecitabine and cisplatin with or without cetuximab for patients with previously untreated advanced gastric cancer (EXPAND): a randomised, open-label phase 3 trial. Lancet Oncol 2013;14:490-9.

46. Waddell T, Chau I, Cunningham D, Gonzalez D, Okines AF, Okines C, Wotherspoon A, Saffery C, Middleton G, Wadsley J, Ferry D, Mansoor W, Crosby T, Coxon F, Smith D, Waters J, Iveson T, Falk S, Slater S, Peckitt C, Barbachano Y. Epirubicin, oxaliplatin, and capecitabine with or without panitumumab for patients with previously untreated advanced oesophagogastric cancer (REAL3): a randomised, open-label phase 3 trial. Lancet Oncol 2013;14:481-9.

47. Ling Y, Chen J, Tao M, Chu X, Zhang X. A pilot study of nimotuzumab combined with cisplatin and 5-FU in patients with advanced esophageal squamous cell carcinoma. J Thorac Dis 2012:4:58-62.

48. Shah MA, Ramanathan RK, Ilson DH, Levnor A, D’Adamo D, O'Reilly E, Tse A, Trocola R, Schwartz L, Capanu M, Schwartz GK, Kelsen DP. Multicenter phase II study of irinotecan, cisplatin, and bevacizumab in patients with metastatic gastric or gastroesophageal junction adenocarcinoma. J Clin Oncol 2006;24:5201-6.

49. Shah MA, Jhawer M, Ilson DH, Lefkowitz RA, Robinson E, Capanu M, Kelsen DP. Phase II study of modified docetaxel, cisplatin, and fluorouracil with bevacizumab in patients with metastatic gastroesophageal adenocarcinoma. J Clin Oncol 2011;29:868-74.

50. Kamangar F, Dores GM, Anderson WF. Patterns of cancer incidence, mortality, and prevalence across five continents: defining priorities to reduce cancer disparities in different geographic regions of the world. $J$ Clin Oncol 2006;24:2137-50.

51. Bang YJ, Van Cutsem E, Feyereislova A, Chung HC, Shen L, Sawaki A, Lordick F, Ohtsu A, Omuro Y, Satoh T, Aprile G, Kulikov E, Hill J, Lehle M, Ruschoff J, Kang YK. Trastuzumab in combination with chemotherapy versus chemotherapy alone for treatment of HER2-positive advanced 
gastric or gastro-oesophageal junction cancer (ToGA): a phase 3, open-label, randomised controlled trial. Lancet 2010;376:687-97.

52. Fuchs CS, Tomasek J, Yong CJ, Dumitru F, Passalacqua R, Goswami C, Safran H, dos Santos LV, Aprile G, Ferry DR, Melichar B, Tehfe M, Topuzov E, Zalcberg JR, Chau I, Campbell W, Sivanandan C, Pikiel J, Koshiji M, Hsu Y, Liepa AM, Gao L, Schwartz JD, Tabernero J. Ramucirumab monotherapy for previously treated advanced gastric or gastro-oesophageal junction adenocarcinoma (REGARD): an international, randomised, multicentre, placebo-controlled, phase 3 trial. Lancet 2014;383:31-9.

53. Wilke H, Muro K, Van Cutsem E, Oh SC, Bodoky G, Shimada Y, Hironaka S, Sugimoto N, Lipatov O, Kim TY, Cunningham D, Rougier P, Komatsu Y, Ajani J, Emig M, Carlesi R, Ferry D, Chandrawansa K, Schwartz JD, Ohtsu A. Ramucirumab plus paclitaxel versus placebo plus paclitaxel in patients with previously treated advanced gastric or gastro-oesophageal junction adenocarcinoma (RAINBOW): a double-blind, randomised phase 3 trial. Lancet Oncol 2014;15:1224-35.

54. Ohtsu A, Shah MA, Van Cutsem E, Rha SY, Sawaki A, Park SR, Lim HY, Yamada Y, Wu J, Langer B, Starnawski M, Kang YK. Bevacizumab in combination with chemotherapy as first-line therapy in advanced gastric cancer: a randomized, double-blind, placebo-controlled phase III study. J Clin Oncol 2011;29:3968-76.

55. Ohtsu A, Ajani JA, Bai YX, Bang YJ, Chung HC, Pan HM, Sahmoud T, Shen L, Yeh KH, Chin K, Muro K, Kim YH, Ferry D, Tebbutt NC, Al-Batran SE, Smith H, Costantini C, Rizvi S, Lebwohl D, Van Cutsem E. Everolimus for previously treated advanced gastric cancer: results of the randomized, double-blind, phase III GRANITE-1 study. J Clin Oncol 2013;31:3935-43.

56. Janjigian YY, Werner D, Pauligk C, Steinmetz K, Kelsen DP, Jager E, Altmannsberger HM, Robinson E, Tafe LJ, Tang LH, Shah MA, Al-Batran SE. Prognosis of metastatic gastric and gastroesophageal junction cancer by HER2 status: a European and USA International collaborative analysis. Ann Oncol 2012;23:2656-62.

57. Spratlin JL, Cohen RB, Eadens M, Gore L, Camidge DR, Diab S, Leong S, O'Bryant C, Chow LQ, Serkova NJ, Meropol NJ, Lewis NL, Chiorean EG, Fox F, Youssoufian H, Rowinsky EK, Eckhardt SG. Phase I pharmacologic and biologic study of ramucirumab (IMC-1121B), a fully human immunoglobulin G1 monoclonal antibody targeting the vascular endothelial growth factor receptor-2. J Clin Oncol 2010;28:780-7.

58. Ueda S, Satoh T, Gotoh M, Gao L, Doi T. A phase ib study of safety and pharmacokinetics of ramucirumab in combination with Paclitaxel in patients with advanced gastric adenocarcinomas. Oncologist 2015;20:493-4.

59. Jemal A, Bray F, Center MM, Ferlay J, Ward E, Forman D. Global cancer statistics. CA Cancer J Clin 2011;61:69-90.

60. Wieser M, Sauerland S, Arnold D, Schmiegel W, Reinacher-Schick A. Peri-operative chemotherapy for the treatment of resectable liver metastases from colorectal cancer: a systematic review and meta-analysis of randomized trials. BMC Cancer 2010;10:309.

61. Fearon ER, Vogelstein B. A genetic model for colorectal tumorigenesis. Cell 1990;61:759-67.

62. Cunningham D, Humblet Y, Siena S, Khayat D, Bleiberg H, Santoro A, Bets D, Mueser M, Harstrick A, Verslype C, Chau I, Van Cutsem E. Cetuximab monotherapy and cetuximab plus irinotecan in irinotecan-refractory metastatic colorectal cancer. N Engl J Med 2004;351:337-45.
63. Hurwitz H, Fehrenbacher L, Novotny W, Cartwright T, Hainsworth J, Heim W, Berlin J, Baron A, Griffing S, Holmgren E, Ferrara N, Fyfe G, Rogers B, Ross R, Kabbinavar F. Bevacizumab plus irinotecan, fluorouracil, and leucovorin for metastatic colorectal cancer. $N$ Engl J Med 2004;350:2335-42.

64. Mayer RJ. Targeted therapy for advanced colorectal cancer-more is not always better. $N$ Engl $J$ Med 2009;360:623-5.

65. Saltz LB, Meropol NJ, Loehrer PJ Sr, Needle MN, Kopit J, Mayer RJ. Phase II trial of cetuximab in patients with refractory colorectal cancer that expresses the epidermal growth factor receptor. J Clin Oncol 2004;22:1201-8.

66. Kim KJ, Li B, Winer J, Armanini M, Gillett N, Phillips HS, Ferrara N. Inhibition of vascular endothelial growth factor-induced angiogenesis suppresses tumour growth in vivo. Nature 1993;362:841-4.

67. Gerber HP, Ferrara N. Pharmacology and pharmacodynamics of bevacizumab as monotherapy or in combination with cytotoxic therapy in preclinical studies. Cancer Res 2005;65:671-80.

68. Fuchs CS, Marshall J, Mitchell E, Wierzbicki R, Ganju V, Jeffery M, Schulz J, Richards D, Soufi-Mahjoubi R, Wang B, Barrueco J. Randomized, controlled trial of irinotecan plus infusional, bolus, or oral fluoropyrimidines in first-line treatment of metastatic colorectal cancer: results from the BICC-C Study. J Clin Oncol 2007;25:4779-86.

69. Cassidy J, Clarke S, Diaz-Rubio E, Scheithauer W, Figer A, Wong R, Koski S, Rittweger K, Gilberg F, Saltz L. XELOX vs FOLFOX-4 as first-line therapy for metastatic colorectal cancer: NO16966 updated results. Br J Cancer 2011;105:58-64.

70. Hochster HS, Hart LL, Ramanathan RK, Childs BH, Hainsworth JD, Cohn AL, Wong L, Fehrenbacher L, Abubakr Y, Saif MW, Schwartzberg L, Hedrick E. Safety and efficacy of oxaliplatin and fluoropyrimidine regimens with or without bevacizumab as first-line treatment of metastatic colorectal cancer: results of the TREE Study. J Clin Oncol 2008;26:3523-9.

71. Saltz LB, Clarke S, Diaz-Rubio E, Scheithauer W, Figer A, Wong R, Koski S, Lichinitser M, Yang TS, Rivera F, Couture F, Sirzen F, Cassidy J. Bevacizumab in combination with oxaliplatin-based chemotherapy as first-line therapy in metastatic colorectal cancer: a randomized phase III study. $J$ Clin Oncol 2008;26:2013-9.

72. Allegra CJ, Yothers G, O’Connell MJ, Sharif S, Petrelli NJ, Colangelo LH, Atkins JN, Seay TE, Fehrenbacher L, Goldberg RM, O'Reilly S, Chu L, Azar CA, Lopa S, Wolmark N. Phase III trial assessing bevacizumab in stages II and III carcinoma of the colon: results of NSABP protocol C-08. J Clin Oncol 2011;29:11-6.

73. de Gramont A, Van Cutsem E, Schmoll HJ, Tabernero J, Clarke S, Moore MJ, Cunningham D, Cartwright $\mathrm{TH}$, Hecht JR, Rivera F, Im SA, Bodoky G, Salazar R, Maindrault-Goebel F, Shacham-Shmueli E, Bajetta E, Makrutzki M, Shang A, Andre T, Hoff PM. Bevacizumab plus oxaliplatin-based chemotherapy as adjuvant treatment for colon cancer (AVANT): a phase 3 randomised controlled trial. Lancet Oncol 2012;13:1225-33.

74. Tabernero J. The role of VEGF and EGFR inhibition: implications for combining anti-VEGF and anti-EGFR agents. Mol Cancer Res 2007;5:203-20.

75. Van Cutsem E, Kohne CH, Hitre E, Zaluski J, Chang Chien CR, Makhson A, D’Haens G, Pinter T, Lim R, Bodoky G, Roh JK, Folprecht G, Ruff P, Stroh C, Tejpar S, Schlichting $M$, Nippgen J, Rougier P. Cetuximab and 
chemotherapy as initial treatment for metastatic colorectal cancer. N Engl J Med 2009;360:1408-17.

76. Heinemann V, von Weikersthal LF, Decker T, Kiani A, VehlingKaiser U, Al-Batran SE, Heintges T, Lerchenmüller C, Kahl C, Seipelt G, Kullmann F, Stauch M, Scheithauer W, Hielscher J, Scholz M, Müller S, Link H, Niederle N, Rost A, Höffkes HG, Moehler M, Lindig RU, Modest DP, Rossius L, Kirchner T, Jung A, Stintzing S. FOLFIRI plus cetuximab versus FOLFIRI plus bevacizumab as first-line treatment for patients with metastatic colorectal cancer (FIRE-3): a randomised, openlabel, phase 3 trial. Lancet Oncol 2014;10:1065-75.

77. Zhang $\mathrm{D}, \mathrm{Ye} \mathrm{J}, \mathrm{Xu} \mathrm{T}$, Xiong B. Treatment related severe and fatal adverse events with cetuximab in colorectal cancer patients: a meta-analysis. $J$ Chemother 2013;25:170-5.

78. Gravalos C, Cassinello J, Garcia-Alfonso P, Jimeno A. Integration of panitumumab into the treatment of colorectal cancer. Crit Rev Oncol Hematol 2010;74:16-26.

79. Douillard JY, Siena S, Cassidy J, Tabernero J, Burkes R, Barugel M, Humblet Y, Bodoky G, Cunningham D, Jassem J, Rivera F, Kocakova I, Ruff P, Blasinska-Morawiec M, Smakal M, Canon JL, Rother M, Oliner KS, Wolf M, Gansert J. Randomized, phase III trial of panitumumab with infusional fluorouracil, leucovorin, and oxaliplatin (FOLFOX4) versus FOLFOX4 alone as first-line treatment in patients with previously untreated metastatic colorectal cancer: the PRIME study. J Clin Oncol 2010;28:4697-705.

80. Douillard JY, Oliner KS, Siena S, Tabernero J, Burkes R, Barugel M, Humblet Y, Bodoky G, Cunningham D, Jassem J, Rivera F, Kocakova I, Ruff P, Blasinska-Morawiec M,
Smakal M, Canon JL, Rother M, Williams R, Rong A, Wiezorek J, Sidhu R, Patterson SD. Panitumumab-FOLFOX4 treatment and RAS mutations in colorectal cancer. N Engl J Med 2013;369:1023-34.

81. Wilhelm SM, Dumas J, Adnane L, Lynch M, Carter CA, Schutz G, Thierauch KH, Zopf D. Regorafenib (BAY 73-4506): a new oral multikinase inhibitor of angiogenic, stromal and oncogenic receptor tyrosine kinases with potent preclinical antitumor activity. Int $J$ Cancer 2011;129:245-55.

82. Grothey A, Van Cutsem E, Sobrero A, Siena S, Falcone A, Ychou M, Humblet Y, Bouche O, Mineur L, Barone C, Adenis A, Tabernero J, Yoshino T, Lenz HJ, Goldberg RM, Sargent DJ, Cihon F, Cupit L, Wagner A, Laurent D. Regorafenib monotherapy for previously treated metastatic colorectal cancer (CORRECT): an international, multicentre, randomised, placebo-controlled, phase 3 trial. Lancet 2013;381:303-12.

83. Chu QS. Aflibercept (AVE0005): an alternative strategy for inhibiting tumour angiogenesis by vascular endothelial growth factors. Expert Opin Biol Ther 2009;9:263-71.

84. Mitchell EP. Targeted therapy for metastatic colorectal cancer: role of aflibercept. Clin Colorectal Cancer 2013;12:73-85.

85. Van Cutsem E, Tabernero J, Lakomy R, Prenen H, Prausova J, Macarulla T, Ruff P, van Hazel GA, Moiseyenko V, Ferry D, McKendrick J, Polikoff J, Tellier A, Castan R, Allegra C. Addition of aflibercept to fluorouracil, leucovorin, and irinotecan improves survival in a phase III randomized trial in patients with metastatic colorectal cancer previously treated with an oxaliplatin-based regimen. $J$ Clin Oncol 2012;30:3499-506 